\title{
Gender Preference for a Third or More Children: Evidence from Indonesia
}

\author{
Resty Sopiyono, Ahmad Rifki Febrianto
}

\begin{abstract}
Faculty of Economics and Business, Universitas Indonesia, Depok, Indonesia
\end{abstract}
*Corresponding author. Email: elessar.kisar@gmail.com

\begin{abstract}
Indonesia's total fertility rate (TFR) was 2.4 in 2017, slightly lower than the 2002 rate of 2.6. In order to achieve a stable population growth, Indonesia needs to lower its fertility rate to the replacement level of TFR $=2.1$. Studies have revealed that gender preferences regarding offspring are influential in determining the number of children. This paper investigated the gender preference for a third or more children using the 2017 Indonesia Demographic and Health Survey (DHS). The results of the logistic regression analysis reveal that children's sex composition has a significant effect on the desire for additional children. Compared with women who already have two children of different sexes, those who have only sons or only daughters are more likely to want additional children. These results indicate that Indonesian women prefer to have offspring of both sexes.
\end{abstract}

Keywords: fertility, child sex preference, logistic regression, DHS, desire for children

\section{INTRODUCTION}

According to data compiled by the United Nations Population Division in 2019, Indonesia was ranked as the fourth largest population in the world following China, India, and the United States. The total population of Indonesia reported by the 2015 mid-census survey was 255.18 million. This number is $7.38 \%$ higher than that recorded by the 2010 population census, which was 237.64 million.

Table I. Ranking of the Human Development Index (HDI) of ASEAN Countries, 2017

\begin{tabular}{|c|l|c|}
\hline HDI rank & \multicolumn{1}{|c|}{ Country } & HDI \\
\hline 9 & Singapore & 0.932 \\
\hline 39 & Brunei Darussalam & 0.853 \\
\hline 57 & Malaysia & 0.802 \\
\hline 83 & Thailand & 0.755 \\
\hline 113 & Philippines & 0.699 \\
\hline 116 & Indonesia & 0.694 \\
\hline 116 & Vietnam & 0.694 \\
\hline 132 & Timor-Leste & 0.625 \\
\hline 139 & Lao's Democratic & 0.601 \\
\hline 146 & Cambodia & 0.582 \\
\hline 148 & Myanmar & 0.578 \\
\hline
\end{tabular}

Source: UNDP, 2018

However, Indonesia's large population does not translate into reliable human capital. Based on the 2017 data from the United Nations Development Program (UNDP), Indonesia ranked 116 out of 189 countries in the world in the Human Development Index (HDI). Among the ASEAN countries, Indonesia ranked lower than Singapore, Brunei Darussalam, Malaysia, Thailand, and the Philippines. When judged according to UNDP criteria, Indonesia is considered to have a moderate HDI, whereas Malaysia, Brunei Darussalam, and Singapore are among the countries with a very high HDI. This reflects the fact that Indonesia's population still lags behind in many development indicators.

Birth control is the most common solution proposed to control population growth. According to the Indonesian Demographic and Health Survey (Survei Demografi dan Kesehatan Indonesia), Indonesia's total fertility rate (TFR) in 2017 was 2.4, indicating a slight drop from 2.6 in 2002. In order to achieve a stable population growth, Indonesia needs to lower its fertility rate to the replacement level of TFR $=2.1$. 


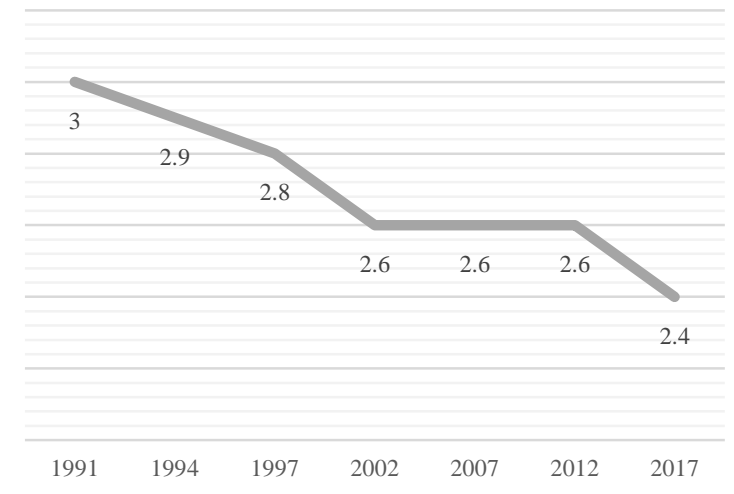

Source: Indonesian DHS (1991-2017)

Figure I. Trends of Indonesia's TFR,1991-2017

Changes in the age structure of Indonesia's population will soon bring about a demographic dividend. In a country undergoing a fast demographic transition, the saving rate increases, resulting in a rapid growth of capital and income. In countries undergoing a slower demographic transition, saving rates and economic growth are slower (Lee, Mason and Miller, 2001). Rapid demographic transition can be achieved by rapidly lowering the fertility rate.

A fertility rate which exceeds the expected rate and an underdeveloped population are a burden for governments, not advantages. In order to control population growth, we need to learn more about fertility behavior and the factors that influence it.

Several studies have revealed that parents' gender preferences concerning children influence the number of children a couple plans to have. Arnold and Kuo (1984) in Fuse (2008) identified the following reasons for parents preferring sons over daughters: (1) maintaining family lineage, (2) employment and financial assistance (with daughters relegated to house work), and (3) companionship. Although son preference is common in many countries, other findings have shown that a clear desire for boys decreased significantly when viewed from a broader perspective (Wood and Bean, 1977).

There are few studies on gender preferences for children in Indonesia using individual data on a national scale. Most studies on gender preferences for children have utilized a qualitative approach. Therefore, this study uses a quantitative approach to investigate the effect of gender composition on women's desires to have children.

\section{LITERATURE REVIEW AND HYPOTHESIS}

\subsection{Theories of Fertility Determinants}

The work of Davis and Blake (1956) offers a sociological theoretical framework for predicting fertility behavior. Davis and Blake put forward factors that influence fertility with reference to what is referred to as "intermediate variables." According to Davis and Blake, social, economic, and cultural factors affecting fertility are defined as "intermediate variables." There are 11 variables that affect fertility: (1) age of entry into a sexual union; (2) permanent celibacy or proportion of women never entering sexual unions; (3) length of reproductive period after entering union; (4) voluntary abstinence; (5) involuntary abstinence (from impotence, illness, or unavoidable but temporary separation); (6) coital frequency; (7) fecundity or infecundity, as affected by involuntary causes; (8) use of contraception; and (9) fecundity or infecundity, as affected by voluntary causes (sterilization, subincision, or medical treatment).

Schultz (1997) says that parents' gender preferences for boys or girls can be explained by the following logic:

i. Net economic value of boys may be greater than daughters. For example, the private return of rate for schooling of boys could be greater than the returns of daughters in the labor market.

ii. In terms of old-age insurance for parents, boys may give a greater economic benefit than girls.

iii. In addition to economic benefits, boys are valued more than girls owing to their specific cultural or religious role, such as maintaining family lineage.

According to Bulatao and Lee (1983), the demand for children does not only refer to the number of children desired but also includes when birth occurs, the time interval between births, and also the desired sex of the child.

\subsection{Empirical Research on the Effects of Gender Composition of Children}

In several studies, it has been shown that the sex of the child influences the number of children desired. Hank and Kohler (2007) conducted research based on results from the Fertility and Family Survey (FFS) conducted in 17 European countries. The results of the study support the findings of previous research regarding gender preference in Western societies, which demonstrates a strong tendency toward mixed-gender preference (wanting one boy and one girl when having children). However, this study also uncovered some unexpected variables. In the Czech Republic, Lithuania, and Portugal, gender preference for children is 
overwhelmingly dependent on the opinions of the female parent. Correspondingly, Yaya and Osanyintupin (2008) also conducted research in Ghana and Nigeria, where they found that the sex of the child affects a woman's desire to have more children.

Research shows that gender preferences are strongly influenced by the level of patriarchy within the society. Inyang-Etoh and Ekanem (2016) conducted a genderbased research on the number of children desired in Nigeria. Nigeria is a patriarchal country where women prefer to have sons over daughters. However, there is a recent trend toward a preference for having children of both sexes. Boys are often preferred because they secure inheritance, please their fathers, and strengthen their parent's marriage. In addition, research conducted by Das Gupta et al. (2003) on China, India, and Korea also confirmed that the patriarchal family system influenced the number of children desired. A strong patriarchal family system greatly influences the preference for sons regardless of rising income, education, or urbanization. Even when women's educational status and participation in the workforce improve, the husband's family benefits most. Education and employment can increase the status of women, but in primarily agrarian societies, such as China and India, this process occurs slowly.

In addition, Nguyen (2018) conducted a study on child gender composition, childbearing, and the effects of female labor participation in Indonesia. She found that Indonesians have a preference for mixed genders for their children. Therefore, additional children reduce the participation of women in the labor force.

\section{DATA SOURCE AND METHODS}

\subsection{Data}

The data used in this study was obtained from the 2017 Indonesian Demographic and Health Survey (DHS). It is the eighth DHS to be administered in Indonesia. The Indonesian DHS is a national survey designed to provide information on birth, death, family planning, and health rates within the country. Similar surveys have also been conducted in Latin American, Asian, and African countries. In general, the Indonesian DHS questions are patterned after the International Demographic and Health Survey (2016).

The 2017 Indonesian DHS was carried out by Statistics Indonesia in collaboration with the Board of National Population and Family Planning and the Ministry of Health. Technical assistance was provided by the United States Agency for International Development.

In 2017, the Indonesian DHS documented the number of households in Indonesia and administered three questionnaires to three target groups: childbearing women aged 15 to 49 years old, married men aged 15 to 54 years old, and male youth aged 15 to 24 years old. In this study, we only used the data obtained from women of childbearing age. The questionnaire included the respondent's background, history of giving birth, knowledge and practice of family planning, health (including the child's), knowledge of AIDS and other sexually transmitted diseases, and other information deemed relevant to the formulation of family planning and health policy.

\subsection{Unit of Analysis}

In this study, the unit of analysis used was women aged 15 to 49 years who are married and have at least two living children. 24.053 women were selected as units of analysis among women of childbearing age that were successfully interviewed.

\subsection{Definition of Variables}

In this study, variables influencing the desire to add children are limited in cases where the respondent already has two or more children. In addition to the details of the question, the desire to add children in this study is limited to two groups: those who want more children and those who do not.

Other responses, such as "not yet decided" or "do not know," are not included in this study. The main independent variable considered was the gender composition of living children. Gender composition variables were divided into three categories: (1) having only sons, (2) having only daughters, and (3) having a son and a daughter.

The decision to have children is also determined by other control-independent variables, such as the number of living children, education, experiences of miscarriage or stillbirth, working status, age, type of residential area, and use of contraception.

For the independency test, we use the chi-squared test for a bivariate analysis. This is a non-parametric test which confirms that the two tested variables have no statistical relationship. Therefore, we expect that the chi-squared test would give a significant result indicating the two variables have a statistical relationship. The chi-square statistic was computed as:

$\sum \frac{(\mathrm{O}-\mathrm{E})^{2}}{\mathrm{E}}=\chi_{\mathrm{df}}^{2}$,

where $\mathrm{df}=(\mathrm{r}-1)(\mathrm{c}-1) ; \mathrm{r}$ and $\mathrm{c}$ indicate the number of rows and columns, respectively.

To find out more about how the main independent variable affects the desire for more children, we will use a binary logistic regression for inferential analysis. The general form of the logistics model to be built is as follows: 


$$
\mathrm{L}_{\mathrm{i}}=\ln \left(\frac{\mathrm{p}_{\mathrm{i}}}{1-\mathrm{p}_{\mathrm{i}}}\right)=\beta_{0}+\beta_{\mathrm{i}} \mathrm{X}_{\mathrm{i}}+\varepsilon
$$

In this model, $p_{i}$ is the probability of the desire to add children in a dichotomized variable setting with 1 indicating "want more children" and 0 indicating "do not want more children." The regression model that will be formed in this study can be written as follows:

\author{
DESIRED $_{\text {CHILD }}=\beta_{0}+\beta_{1} \mathrm{SEX}+\beta_{2}$ CHILD + \\ $\beta_{3} \mathrm{EDU}+\beta_{4} \mathrm{PREM}$
}

$+\beta_{5} \mathrm{WORK}+\beta_{6} \mathrm{AGE}+\beta_{7} \mathrm{RES}+\beta_{8} \mathrm{CONTRA}$

Table II. Definition of Variables

\begin{tabular}{|c|c|c|c|}
\hline Variable & Notation & Operational Definition & Category \\
\hline$(1)$ & $(2)$ & (3) & $(4)$ \\
\hline \multicolumn{4}{|l|}{ Dependent variable } \\
\hline \multirow{2}{*}{$\begin{array}{l}\text { The desire to } \\
\text { add children }\end{array}$} & \multirow{2}{*}{ DESIRED $_{\mathrm{CHILD}}$} & \multirow{2}{*}{$\begin{array}{l}\text { The desire to add children in the future } \\
\text { when they have two or more living children }\end{array}$} & 1. Wants more children \\
\hline & & & 2. Wants no more children* \\
\hline \multicolumn{4}{|l|}{ Independent variables } \\
\hline \multirow{3}{*}{$\begin{array}{l}\text { Gender composition } \\
\text { of children }\end{array}$} & \multirow{3}{*}{ SEX } & \multirow{3}{*}{ Gender composition of all living children } & 1. Have only sons \\
\hline & & & 2. Have only daughters \\
\hline & & & 3. Have son and daughter* \\
\hline Children still alive & CHILD & Number of living children & - \\
\hline \multirow{4}{*}{ Level of education } & \multirow{4}{*}{ EDUC } & \multirow{4}{*}{ Highest level of education } & 1. Higher \\
\hline & & & 2. Secondary \\
\hline & & & 3. Primary \\
\hline & & & 4. No Education* \\
\hline $\begin{array}{l}\text { Experience of } \\
\text { miscarriage or } \\
\text { stillbirth }\end{array}$ & PREM & $\begin{array}{l}\text { A previous pregnancy experience that } \\
\text { ended in miscarriage, abortion, or stillbirth }\end{array}$ & $\begin{array}{l}\text { 1. Yes } \\
\text { 2. No } *\end{array}$ \\
\hline \multirow{2}{*}{ Working status } & \multirow{2}{*}{ WORK } & \multirow{2}{*}{ Working status a week ago } & 1. Working \\
\hline & & & 2. Not working $*$ \\
\hline \multirow{3}{*}{ Age } & \multirow{3}{*}{ AGE } & \multirow{3}{*}{ Age based on last birthday } & $1 . \geq 40$ years \\
\hline & & & 2. $30-39$ years \\
\hline & & & $3 .<30$ years* \\
\hline \multirow{2}{*}{ Type of residence } & \multirow{2}{*}{ RES } & \multirow{2}{*}{ Classification of respondent's residence } & 1. Urban \\
\hline & & & 2. Rural* \\
\hline \multirow{2}{*}{ Contraception usage } & \multirow{2}{*}{ CONTRA } & \multirow{2}{*}{$\begin{array}{l}\text { Use of methods/contraception by } \\
\text { respondents/partners }\end{array}$} & 1. Use \\
\hline & & & 2. Do not use* \\
\hline
\end{tabular}

To ensure that the logistic model is able to accurately describe the influence of independent variables on the dependent variable, it is necessary to test the significance of the model as a whole as well as each individual parameter. Maximum likelihood estimation was used to determine the estimates $\hat{\beta}_{0}$ and $\hat{\beta}=\left(\hat{\beta}_{1}, \hat{\beta}_{2}, \ldots, \hat{\beta}_{k}\right)$. Subsequently, we use marginal effect to see how much the probability of desiring more children was due to changes in independent variable. The marginal effect at the mean for categorical variables therefore shows how $\mathrm{P}(\mathrm{Y}=1)$ changes as the categorical variable changes from 0 to 1 , holding all other variables at their means.

\section{RESULTS AND DISCUSSION}

The results of the cross tabulation analysis in Table III reveal that $38.21 \%$ of women who have only sons want more children. This percentage is higher than those of women who only have daughters and want more children, which is $36.09 \%$. Meanwhile, only $18.61 \%$ of parents with mixed-gender children desire to have more children.

When analyzed in terms of educational level, the percentage of women who want more children is highest among women with a high level of education (31.97\%). Among women with no education, only $21.48 \%$ want more children. Likewise, only $22.61 \%$ of women who completed primary education want more children. Finally, $25.38 \%$ of women with secondary education want more children. Indeed, it seems apparent that an increase in educational level corresponds to a desire to have more children.

When compared with women who do not want more children, women who want more children are more likely to have an experience of miscarriage or stillbirth (25.38\%), to be working $(27.35 \%)$, to be aged below 30 years old $(54.64 \%)$, to live in rural areas $(28.16 \%)$, and not to be currently using contraception (32.96\%).

The result of the bivariate analysis reveals that all the socio-demographic characteristics have a significant impact on women's desires to have more children. The 
results indicate a strong association between the gender composition of children and women's desire to have additional children. Likewise, other variables, such as the number of living children, the mother's educational level, experiences of miscarriage or stillbirth, working status, age, type of residence, and contraception usage, indicate an association with women's desire to add more children.

Table III. Desire for Third and More Children and Socio-Demographic Characteristics

\begin{tabular}{|c|c|c|c|c|c|c|}
\hline \multicolumn{2}{|c|}{ Socio-demographic characteristics } & \multicolumn{2}{|c|}{$\begin{array}{l}\text { Demand for a third or more children } \\
\qquad(\%)\end{array}$} & \multirow{2}{*}{ Total } & \multirow{2}{*}{$\begin{array}{l}\text { Pearson's chi- } \\
\text { square statistic }\end{array}$} & \multirow{2}{*}{ P-value } \\
\hline Variable name & Variable level & $\begin{array}{c}\text { Wants more } \\
\text { children }\end{array}$ & $\begin{array}{l}\text { Wants no more } \\
\text { children }\end{array}$ & & & \\
\hline$(1)$ & $(2)$ & (3) & $(4)$ & $(5)$ & $(6)$ & (7) \\
\hline \multirow{3}{*}{$\begin{array}{l}\text { Gender composition of } \\
\text { children }\end{array}$} & Has only sons & 38.21 & 61.79 & 100 & \multirow{3}{*}{$1,000.00$} & \multirow{3}{*}{$<0.001$} \\
\hline & Has only daughters & 36.09 & 63.91 & 100 & & \\
\hline & Has son and daughters & 18.61 & 81.39 & 100 & & \\
\hline Children still alive & - & 25.07 & 74.93 & 100 & $1,600.00$ & $<0.001$ \\
\hline \multirow{4}{*}{ Level of education } & No education & 21.48 & 78.52 & 100 & \multirow{4}{*}{105.23} & \multirow{4}{*}{$<0.001$} \\
\hline & Primary & 22.61 & 77.39 & 100 & & \\
\hline & Secondary & 25.38 & 74.62 & 100 & & \\
\hline & Higher & 31.97 & 68.03 & 100 & & \\
\hline \multirow{2}{*}{$\begin{array}{l}\text { Experience of } \\
\text { miscarriage/stillbirth }\end{array}$} & Yes & 25.38 & 74.62 & 100 & \multirow{2}{*}{5.10} & \multirow{2}{*}{0.0024} \\
\hline & No & 23.78 & 76.22 & 100 & & \\
\hline \multirow{2}{*}{ Working Status } & Works & 23.48 & 76.52 & 100 & \multirow{2}{*}{46.45} & \multirow{2}{*}{$<0.001$} \\
\hline & Not working & 27.35 & 72.65 & 100 & & \\
\hline \multirow{3}{*}{ Age } & $>=40$ & 8.94 & 91.06 & 100 & \multirow{3}{*}{$3,100.00$} & \multirow{3}{*}{$<0.001$} \\
\hline & $30-39$ & 32.21 & 67.79 & 100 & & \\
\hline & $<30$ & 54.64 & 45.36 & 100 & & \\
\hline \multirow{2}{*}{ Type of residence } & Urban & 21.96 & 78.04 & 100 & \multirow{2}{*}{122.72} & \multirow{2}{*}{$<0.001$} \\
\hline & Rural & 28.16 & 71.84 & 100 & & \\
\hline \multirow[b]{2}{*}{ Contraception usage } & Currently using & 21.61 & 78.39 & 100 & \multirow{2}{*}{349.93} & \multirow[b]{2}{*}{$<0.001$} \\
\hline & Not currently using & 32.96 & 67.04 & 100 & & \\
\hline
\end{tabular}

The results of the logistic regression analysis reveal that the gender composition of children has a significant effect on the desire for additional children. Also, the preferences of mothers with either only sons or only daughters differ greatly from those with mixed-gender offspring. This result is consistent with those of several studies showing that gender preference affects fertility (Hand and Kohler, 2000; Yaya and Osanyintupin, 2008; and Etoh and Ekanem, 2016). Gender preferences for children affect fertility because of higher levels of investment by parents and non-economic values, such as maintaining family lines (Schultz, 1997).

Other significant socio-demographic variables affecting the desire of women to add children include the number of living children, experiences of miscarriage or stillbirth, working status, age, type of residence, and use of contraception. When considering educational level, only secondary education for women has a significant effect on their desire to add children. The results of similar studies also reveal that education influences the desire for children (Wicaksono and Mahendra, 2016; Oktriyanto, Puspitawati and Muflikhati, 2015; and Bagheri and Saadati, 2017). Finally, the type of residence and working status of the mother also affected the number of children desired (Yaya and Osanyintupin, 2008; Kalwij, 2018).
To measure the effect of independent variables on the desire for additional children, we computed the marginal effects from the model. The marginal effect implies that the probability of women with only sons or only daughters to want more children is higher than that of women who already have children of both sexes. As presented in Table $\mathrm{V}$, the probability to desire for more children among women with two or more children who only have sons increased by $0.1095 \%$ or $10.95 \%$ compared with women who already had both a son and a daughter. For women who only have daughters, their probability to desire for more children increased by $8.98 \%$ compared with women who already had a son and a daughter.

These results indicate that Indonesian women who already have two children or more tend to prefer mixedgender children. These findings are in agreement with those of Nguyen (2018). We found that preference for a daughter has a slightly larger effect on the desire for additional children than preference for a son. Although son preference initially dominated in many countries, other findings reveal that a clear desire for boys has decreased significantly when viewed from a broader perspective (Wood and Bean, 1977). According to these studies, when the focus is on the completed family size (actual or desired), the family tends to want at least one child from each sex. 
Table IV. Logistic Regression Estimates

\begin{tabular}{|c|c|c|c|}
\hline Socio-demographic characteristics & Variable level & Coef. & Robust SE \\
\hline (1) & (2) & (3) & (4) \\
\hline \multirow{3}{*}{ Gender composition of children } & Has only sons & $0.6992 * * *$ & 0.0423 \\
\hline & Has only daughters & $0.5836 * * *$ & 0.5836 \\
\hline & Has son and daughters (ref.) & & \\
\hline Children still alive & - & $-0.3748 * * *$ & 0.02 \\
\hline \multirow{4}{*}{ Level of education } & No education (ref.) & & \\
\hline & Primary & -0.1424 & 0.1228 \\
\hline & Secondary & $-0.2592^{* *}$ & 0.1228 \\
\hline & Higher & 0.1039 & 0.129 \\
\hline \multirow{2}{*}{ Experience of miscarriage/stillbirth } & Yes & $0.1475^{* * * *}$ & 0.0437 \\
\hline & No (ref.) & & \\
\hline \multirow{2}{*}{ Working status } & Working & $0.069 * *$ & 0.0351 \\
\hline & Not working (ref.) & & \\
\hline \multirow{3}{*}{ Age } & $>=40$ (ref.) & & \\
\hline & $30-39$ & $1.5957 * * *$ & 0.0423 \\
\hline & $<30$ & $2.3713 * * *$ & 0.0559 \\
\hline \multirow{2}{*}{ Type of residence } & Urban & $-0.3919 * * *$ & 0.0349 \\
\hline & Rural (ref.) & & \\
\hline \multirow{2}{*}{ Contraception usage } & Using & $-0.9891 * * *$ & 0.00368 \\
\hline & Not using (ref.) & & \\
\hline Observation & & 24,053 & \\
\hline Log pseudolikelihood & & $\begin{array}{l}-10939.737 \\
\end{array}$ & \\
\hline Wald chi-square & & 3738.96 & \\
\hline pseudo $R 2$ & & 0.1924 & \\
\hline
\end{tabular}

Hoffman, Thornton, and Mannis (1978) measured how children of valued in terms of psychological satisfaction they gave to parents. When analyzed from this perspective, it is shown that parents want mixedgender children because of the differences in the benefits obtained from each sex (Wood and Bean, 1977; Hoffman, Thornton, and Mannis 1978). Sons were initially considered to have a higher investment value for parents when they became adults. But along with the successes of women's rights and their right to receive higher education, the investment value of daughters is no longer inferior to sons. In addition, girls can act as caregivers to their parents when they become old. Sons allow fathers to participate in men's activates, such as sports, whereas daughters can provide more attractive activities for mothers (Wood and Bean, 1977). Therefore, having a child of each sex allows parents to engage in various types of activities with their children.

The experience of miscarriage, working status, and the age of the woman showed a positive marginal effect. Women who have experienced a miscarriage are more likely to want more children than those who have not. This result confirms those of other studies showing that women with a history of child mortality have a greater tendency to have more than two children (Wicaksono and Mahendra, 2016).

The number of living children, the type of residence, and the use of contraception confirm expected results. The marginal effect on these three variables reveals a negative result. The probability of women wanting to have more children decreases as the number of living children increases. The probability of women in urban areas wanting to have more children declined by $5.83 \%$ compared with that of women living in rural areas. Women living in rural areas tend to want more children than those who live in urban areas (Yaya and Osanyintupin, 2008; Bagheri and Saadati, 2017). In addition, at $15.67 \%$, women who use contraception also exhibit a reduced probability of wanting more children compared with those who do not.

Table V. Marginal Effect on Binary Logistic Regression

\begin{tabular}{|c|c|c|}
\hline $\begin{array}{l}\text { Socio-demographic } \\
\text { characteristics }\end{array}$ & Variable level & $\mathrm{dy} / \mathrm{dx}$ \\
\hline$(1)$ & $(2)$ & (3) \\
\hline \multirow{3}{*}{$\begin{array}{l}\text { Sex composition of } \\
\text { children }\end{array}$} & Has only sons & 0.1095 \\
\hline & Has only daughters & 0.0898 \\
\hline & Has son and daughters (ref.) & \\
\hline $\begin{array}{l}\text { The number of } \\
\text { children still alive }\end{array}$ & - & -0.5557 \\
\hline \multirow{4}{*}{ Level of education } & No education (ref.) & \\
\hline & Primary & -0.2177 \\
\hline & Secondary & -0.0389 \\
\hline & Higher & 0.0164 \\
\hline \multirow{2}{*}{$\begin{array}{l}\text { Experience of } \\
\text { miscarriage/stillbirth }\end{array}$} & Yes & 0.0222 \\
\hline & No (ref.) & \\
\hline \multirow{2}{*}{ Working status } & Working & 0.0102 \\
\hline & Not working (ref.) & \\
\hline \multirow{3}{*}{ Age } & $\geq 40$ (ref.) & \\
\hline & $30-39$ & 0.2196 \\
\hline & $<30$ & 0.3814 \\
\hline \multirow{2}{*}{ Type of residence } & Urban & -0.0583 \\
\hline & Rural (ref.) & \\
\hline \multirow{2}{*}{ Contraception usage } & Using & -0.1567 \\
\hline & Not using (ref.) & \\
\hline
\end{tabular}

In terms of education, only women's secondary educational level has a significant and negative marginal effect. This means that women with secondary education opportunities will exhibit a preference for more children, which is $3.89 \%$ lower than uneducated 
women. This result agrees with that of Oktriyanto, Puspitawati and Muflikhati (2015), who showed that women with higher education will tend to want fewer children than those with little education.

\section{CONCLUSION}

The results revealed that the gender composition of children significantly influenced the desire to add children. Compared with women with a child of each sex, women who have only sons or only daughters are more likely to want more children. These results indicate that Indonesian women are more likely to prefer having both a son and a daughter.

Other socio-demographic variables affecting the desire to add children were the number of living children, experiences of miscarriage or stillbirth, working status, age, type of residence, and use of contraception. For education, only secondary education for women had a significant effect.

To improve family planning initiatives launched by the government, it is important to understand and analyze the characteristics of women of childbearing age. This makes it easier to predict birth reduction. One suggestion that can be given from the results of this study are to re-socialize small-sized family norms.

We realize that the desire for children does not only involve the preferences of women but also the preference of the husband. For the next study, this issue could be included as a control variable or examined through the use of a different model. Furthermore, considering the high diversity of regional culture that may assign different values to children, this study could be improved by adding regional or cultural factors.

\section{REFERENCES}

[1] Badan Pusat Statistik. (2016) Pedoman BPS Provinsi SDKI 2017. Jakarta: Badan Pusat Statistik.

[2] Bagheri, A. and Saadati, M. (2017) 'Factors affecting the demand for a third child among Iranian women', 7(1), pp1536-1543. https://doi.org/10.22038/jmrh.2018.25186.1275.

[3] Bulatao, R.A. and Lee, R. D. (eds.) (1983) Determinants of Fertility in Developing Countries: A Summary of Knowledge. Washington: National Academy Press.

[4] Das Gupta, M., Jiang, Z., Li, B., Xie, Z., Woojin, C. and Bae, H.O. (2003) 'Why is son preference so persistent in East and South Asia? A cross-country study of China, India and the Republic of Korea', Journal of Development Studies, 40(2), pp153-187. https://doi.org/10.1080/00220380412331293807.
[5] Davis, K. and Blake, J. (1956) 'Social structure and fertility: An analytic framework', Economic Development and Cultural Change, 4(3), pp211235.

[6] Fuse, K. (2008) Gender Preferences for Children: A Multi-Country Study. The Ohio State Unversity. The Ohio State Unversity.

[7] Hank, K. and Kohler, H.-P. (2000). 'Gender preferences for children in Europe: Empirical results from 17 FFS countries', Demographic Research, 2(1). https://doi.org/10.4054/DemRes.2000.2.1.

[8] Hoffman, L.W., Thornton, A. and Manis, J. D. (1978) 'The value of children to parents in the United States', Journal of Population Behavioral, Social, and Environmental Issues, 1(2), pp91-131. https://doi.org/10.1007/bf01277597.

[9] Inyang-Etoh, E.C. and Ekanem, A.M. (2016) 'Child-sex preference and factors that influenced such choices among women in an obstetric population in Nigeria', Open Access Library Journal, 03(10), pp1-10. https://doi.org/10.4236/oalib.1103005.

[10] Kalwij, A.S. (2018) 'The effects of female employment status on the presence and number of children', Journal of Population Economics, 13(2), pp221-239. https://www.jstor.org/stable/20007712.

[11] Lee, R.D., Mason, A. and Miller, T. (2001) 'Saving, wealth, and population' in Birdsall, N., Kelley, A.C. and Sinding, S.W. (eds.) Population Matters: Demographic Change, Economic Growth, and Poverty in The Developing World. New York: Oxford University Press, p. 137

[12] Nguyen, G. (2018) 'Sibling-sex composition, childbearing and female labour market outcomes in Indonesia', Journal of Population Research, 36, pp13-34. https://doi.org/10.1007/s12546-018-9210-2

[13] Oktriyanto, Puspitawati, H. and Muflikhati, I. (2015) 'Nilai Anak dan Jumlah Anak yang Diinginkan Pasangan Usia Subur di Wilayah Perdesaan dan Perkotaan' Jur. Ilm. Kel. \& Kons, $8(1)$, pp1-9. https://doi.org/10.18632/oncotarget.7239.

[14] Schultz, T.P. (1997) 'Demand for children in low income countries' in Rosenzweig, M.R. (ed.). Handbook of Population and Family Economics, New York: Elsevier, vol 1, pp. 349-430 https://doi.org/10.1016/S1574-003X(97)80025-6.

[15] Wicaksono, F. and Mahendra, D. (2016) 'Determinan Fertilitas: Suatu Pendekatan Multilevel', Jurnal Ilmiah Widya, 3(3), pp134-139. 
[16] Wood, C.H., \& Bean, F.D. (1977) 'Offspring gender and family size: Implications from a comparison of Mexican Americans and Anglo Americans', Journal of Marriage and the Family, 39(1), p129. https://doi.org/10.2307/351069.
[17] Yaya, O.S. and Osanyintupin, O.D. (2008) 'Determinants of desired and actual number of children and the risk of having more than two children in Ghana and Nigeria', MPRA, (11767). 